\title{
Correction to: Effects of salinity and nutrients on water hyacinth and its biological control agent, Neochetina bruchi
}

\author{
Emily Bick (D) Elvira S. de Lange • Cindy R. Kron • Lorena da Silva Soler • \\ Jessie Liu $\cdot$ Hoang Danh Nguyen
}

Published online: 24 June 2020

(C) Springer Nature Switzerland AG 2020

\section{Correction to: \\ Hydrobiologia \\ https://doi.org/10.1007/s10750-020-04314-x}

Due to an unfortunate turn of events, the maiden name of the third author was displayed in the original publication and it should have read Cindy R. Kron. The original article has been corrected and the proper representation of the authors' names and their affiliation is also listed here.

Publisher's Note Springer Nature remains neutral with regard to jurisdictional claims in published maps and institutional affiliations.
The original article can be found online at https:// doi.org/10.1007/s10750-020-04314-x.

E. Bick $(\bowtie) \cdot$ E. S. de Lange - J. Liu · H. D. Nguyen Department of Entomology and Nematology, University of California Davis, 1 Shields Avenue, 367 Briggs Hall, Davis, CA 95616, USA

e-mail: enbick@ucdavis.edu

E. Bick

Department of Plant and Environmental Sciences, University of Copenhagen, Thorvaldsensvej 40,

1871 Frederiksberg C, Denmark

C. R. Kron

Cooperative Extension, Division of Agriculture and Natural Resources, University of California, 133 Aviation Blvd., Ste. 109, Santa Rosa, CA 95403-2894, USA

L. da Silva Soler

Universidade Federal do Paraná - Setor de Ciências Agrárias - Rua dos Funcionários, 1540 - Juvevê, Curitiba, PR 80035-050, Brazil 